\title{
Criminal Seduction and Women's Citizenship in Iowa, 1865-1879
}

\author{
SHARON ROMEO
}

IN COURT in July 1876 Nancy E. Haygood testified that her neighbor, A. F. Bell, had persuaded her to engage in sexual intercourse. At the time of her seduction, Haygood was a 20-yearold resident of Mills County, Iowa. The couple lived about a mile from each other and had become engaged earlier that year. According to Haygood, Bell had pursued her for sexual intercourse over the course of several months before she eventually capitulated to his wishes. When Bell was tried for felonious seduction, Haygood told the court that she believed him when he promised that "he wouldn't harm me and wanted me to have confidence in him." The jury in the case ultimately convicted Bell and sentenced him to a "term" in the penitentiary. ${ }^{1}$

Seduction cases such as State $v$. Bell illustrate how criminal seduction laws promoted a concept of gendered citizenshipthe legal logic that demanded that men and women be allocated the rights and obligations of citizenship based on their sex. ${ }^{2}$ The Iowa Code of 1851 included a seduction statute that allowed the legal system to prosecute "if any person seduce and debauch any unmarried woman of previously chaste character." 3 Iowa's

1. State v. Bell, 49 Iowa 440 (1878), "Appellant's Abstract of Evidence," 11.

2. The rights and obligations of citizenship have historically been connected to gender identity in the United States. See Linda K. Kerber, No Constitutional Right to Be Ladies: Women and the Obligations of Citizenship (New York, 1998).

3. Code of Iowa, 1851, ch. 138, § 2586, 262; Code of Iowa, 1873, ch. 2, § 3867, 3868; John E. Briggs, History of Social Legislation in Iowa (Iowa City, 1915), 52.

THE ANNALS OF IOWA 79 (Winter 2020). (C) State Historical Society of Iowa, 2020. 
seduction statute provided special protection for the female gender from male libertines.

Iowa's courts began to affirm felonious conviction for seduction during Reconstruction, which was a period of intense discussion in the state about the political enfranchisement of African Americans and women. Ultimately, the legal logic of criminal seduction undermined the legitimacy of women's claims to political enfranchisement. As Iowans debated the meanings of capacity and consent for female citizens, seduction convictions implied that it would be inappropriate to enfranchise women as political voters. The virtue and liberty of women were best protected within a marital relationship. Sex and politics mingled as legislators and lawyers discussed women's right to consent in both governmental and marital relationships.

An analysis of Reconstruction-era seduction cases like State $v$. Bell demonstrates a historical trajectory in which the Iowa Supreme Court established who needed to be protected by the criminal seduction statute. The circumstances of seduction cases changed in the years after the Civil War, especially after 1870, a year the Iowa legislature voted on women's enfranchisement. As the 1870s progressed, the courts identified adult women as vulnerable to criminal seduction.

This article examines State v. Bell (1878) and four additional appellate seduction cases: State $v$. Carron (1865), State $v$. Shean (1871), State v. Kingsley (1874), and State v. Haven (1876). Iowa's Supreme Court affirmed convictions in the first two cases and reversed the latter two. ${ }^{4}$ The affirmation of felony seduction convictions began during the years of Reconstruction, but the later reversal decisions show more clearly how the court imposed legal obligations for adults based on gender difference through its definition of a seducible woman.

\section{The Legal Logic of Seduction}

State $v$. Bell presents circumstances typical of seduction cases affirmed by Iowa's Supreme Court during the Reconstruction era. The victim was defined as an adult woman who had reached 
her majority at the time of her seduction. The couple had "kept company" for a substantial period of time, and A. F. Bell had proposed marriage to his victim. Nancy Haygood believed what she was told and claimed that she was "tricked" by Bell's persuasion and seemingly kind character. Seduction was always a verbal act: a false promise, artifice, flattery, or deception. ${ }^{5}$

Seduction appeared in the first official code of Iowa as a criminal offense that could be punished by a maximum of five years or, for less aggravated instances, "by a fine not exceeding one thousand dollars and imprisonment in the county jail not exceeding one year." Iowa's code of laws also contained a separate classification of offenses against chastity, morality, and decency. Crimes in this area included adultery, bigamy, or lewdness, when women and men "lewdly and viciously associate and cohabit together." Unlike these crimes, speech was a necessary component of a seduction conviction. The code punished men for the misleading speech claims that accompanied a debauchery of a "chaste" woman. ${ }^{6}$

A. F. Bell's seduction conviction hinged on whether he "induced" Haywood's capitulation through deceptive language. By 1878, the year Bell's lawyers appealed his case, the Iowa Supreme Court had solidified its definition of seducible women.

5. State v. Bell, 49 Iowa 440 (1878), "Appellant's Abstract of Record," 4, "Appellant's Abstract of Evidence," 11, 12, 14.

6. Code of Iowa, 1851, ch. 138, § 2586; Code of Iowa, 1873, ch. 9, § 4008, 4011, 4012. A number of authors have written on various aspects of the history of seduction in the nineteenth-century United States. On the criminalization of seduction, see Lori D. Ginzberg, Women and the Work of Benevolence: Morality, Politics, and Class in the Nineteenth-Century United States (New Haven, CT, 1990), 77-79; Mary P. Ryan, Women in Public: Between Banners and Ballots, 1825-1880 (Baltimore, 1990), 100-102; and Mary Frances Berry, "Judging Morality: Sexual Behavior and Legal Consequences in the Late Nineteenth-Century South," Journal of American History 78 (1991), 848-53. On the history of seduction as a tort, see Jane E. Larson, "Women Understand So Little, They Call My Good Nature 'Deceit': A Feminist Rethinking of Seduction," Columbia Law Review 93 (1993), 374-472; and Lea VanderVelde "The Legal Ways of Seduction," Stanford Law Review 48 (1996), 817-900. On the nineteenth-century identification of seduction as one cause of prostitution, see Sharon Elizabeth Wood, The Freedom of the Streets: Work, Citizenship and Sexuality in a Gilded Age City (Chapel Hill, NC, 2005), 80. For background on the New York Female Moral Reform Society, see Carroll Smith-Rosenberg, Disorderly Conduct: Visions of Gender in Victorian America (New York, 1985), 113-28. 
When Bell appealed his conviction to the Iowa Supreme Court, Chief Justice Joseph Beck noted that a seducer must, through the use of "flattery, promises, or other arts or devices," influence the will of the victim. ${ }^{7}$ Although the seduced woman ultimately capitulates, her consent resulted from the libertine's deception or his powerful skills of persuasion.

In State v. Bell, Iowa's Supreme Court affirmed the conviction and jail time, agreeing that Haygood yielded to Bell only after he falsely promised to marry her and encouraged her consent with "flatteries and protestations of love." 8 Haygood testified that she had consented because "he persuaded, and coaxed, and asked how I could refuse him when he asked so nice." The crime of seduction could not have occurred unless she believed Bell's statements; the victim's reason and will were won over because she believed his false promises, lies, and expressions of affection. She was unable to see through his deceptive speech with the power of her reason; her will was too weak to resist his verbal entreaties. Bell corrupted Haygood through his more powerful will and speech. As his victim testified to a jury of 12 men, "I believed everything he told me, and worshiped him." Haygood further explained to the jury, "I was seated in his lap, leaning up against him, and when I consented I got up and straddled over his lap." 9

Bell's seductive words convinced a "chaste" woman to submit to his appeals. Under Iowa law, his verbal acts obliged him to act as a protector of his emotional dependent. The profession of love was instrumental in establishing a man's legal obligation to protect his future wife. In seduction cases, the love of a woman for her seducer was of "the highest materiality" because the declaration of his sentiments indicated that she believed he would protect her. ${ }^{10}$ If a man lied to a woman about the quality of his affections, she would misunderstand his subsequent obligations to her. This principle remained in place for decades. For example, in the case of State v. Gardner (1923), the Iowa Supreme Court

7. State v. Bell, 442.

8. State v. Bell, "Appellant's Abstract of Record," 4.

9. State v. Bell, “Appellant's Abstract of Evidence," 11, 14, 12.

10. State v. Burns (1903), 119 Iowa 668. 
affirmed a conviction because the defendant "professed to love her and promised to marry her and protect her." 11

Historically, the obligation to protect household dependents has played a critical role in establishing legal power over individuals. ${ }^{12}$ If men refused to protect "chaste" women, they attacked aspects of a power structure that, at least rhetorically, required men to claim that they protected their dependents. Throughout the nineteenth century, men used their claims of "protection" to justify male power. The seduction statute allowed the state of Iowa to label acts of seduction as deviant behavior for white men. ${ }^{13}$ If these "seducers" failed to live up to their obligations of citizenship, then the legal system made a show of punishing them.

State v. Bell illustrates how Iowa's seduction statute, drawn from republican political theory, was centrally concerned with the free consent of an individual when entering into a relationship. ${ }^{14}$

11. State v. Gardner (1923), 195 Iowa 444.

12. Nancy Fraser and Linda Gordon, "Contract versus Charity: Why Is There No Social Citizenship in the United States?" Socialist Review (1992), 56; Kerber, No Constitutional Right to Be Ladies.

13. In the nineteenth century, industrialization and urbanization promoted the belief that male power derived from the status of "breadwinner." As more families moved from farms to towns and cities, the concept of separate gendered "spheres" allocated the duty of economic and political activities to men. Linda Kerber demonstrated the immense historical importance of this separate spheres ideology in her groundbreaking article, "Separate Spheres, Female Worlds, Woman's Place: The Rhetoric of Women's History," Journal of American History 75 (1988), 9-39. For work on northeastern industrialization, the hidden value of unpaid housework, and the "cult" of the male breadwinner in the nineteenth-century United States, see Jeanne Boydston, Home and Work: Housework, Wages, and the Ideology of Labor in the Early Republic (New York, 1990). Boydston quantified the hidden value of women's unpaid work that was obscured by the "separate spheres" ideology. On the meaning of white male protection and its role in upholding the power structure of the antebellum South, see Bertram Wyatt-Brown, Southern Honor: Ethics and Behavior in the Old South (New York, 1982), 51; Victoria E. Bynum, Unruly Women: The Politics of Social and Sexual Control in the Old South (Chapel Hill, NC, 1992), 6-8; and Jacquelyn Dowd Hall, "The Mind that Burns in Each Body" in Powers of Desire: The Politics of Sexuality, ed. Ann Snitowk, Christine Stansell, and Sharon Thompson (New York, 1983), 334-37.

14. Scholars have addressed the gendered aspects of republican political theory. See, for example, Jan Lewis, "The Republican Wife: Virtue and Seduction in the Early Republic," William and Mary Quarterly 44 (1987), 689-721. On how the gendered nature of contract theory lies at the basis of republican political theory, 
Deceptive speech on the part of a political representative corrupts the liberty of citizens in a republic. One of Nancy Haygood's most important political choices in her life would be her consent to a proposal of marriage. A husband, in the nineteenth-century United States, was the proper political representative of his wife and dependents. In fact, he derived his status as political representative through the dependence of his household on his relationship to the state. When A. F. Bell spoke falsely to Haygood, an unmarried woman, he exerted illegitimate authority over her person. Haygood could not "voluntarily" consent to a sexual relationship with Bell outside of the promise of marriage because she lacked the capacity to understand his true motives.

The seducer's oratory undermined the unmarried woman's mastery of her reason, her will, and her body. Iowa's Supreme Court interpreted seductive speech as a sexual attack, and it was the seducer's voice, not his body, that presented the greater threat to a woman's virtue. Speech itself was wielded by the seducer as a sexual assault, both on a woman's body and on her virtuous mind. Iowa's seduction statute provided special protection for the female gender from male libertines.

The underlying logic of seduction narratives accepts fundamental sexual differences between men and women. Only a woman could be a victim of this crime; a female defendant was not possible within the language of the statute. ${ }^{15}$ The Iowa Supreme Court established the crime of seduction as more than

see Carole Pateman, The Sexual Contract (Stanford, CA, 1988). On the relationship of gender to slavery in the antebellum South's political ideology, see Stephanie McCurry, "The Two Faces of Republicanism: Gender and Proslavery Politics in Antebellum South Carolina," Journal of American History 78 (1992), 1245-64. For a discussion of the Edmund-Tucker Act, which disfranchised the women of Utah, see Sarah Barringer Gordon, " 'The Liberty of Self-Degradation': Polygamy, Woman Suffrage, and Consent in Nineteenth-Century America," Journal of American History 83 (1996).

15. The Iowa Supreme Court could have affirmed convictions for extramarital sexual intercourse or equated chastity with virginity, but the court did not do so in the years leading up to Reconstruction. Of 16 criminal seduction cases appealed from 1865 to 1879 , the Iowa Supreme Court affirmed 10 convictions. Seven of those cases were affirmed after 1876, showing that at that time the court had defined the points of law clearly so that the instructions given by district court more closely matched the Supreme Court's legal interpretation of the seduction statute. 
the act of sexual intercourse, and chastity as "actual personal virtue in the female." 16

The seduction statute assumed that essential sexual differences necessitated legal rules for each gender. It divided all women into one of three categories: seducible, married, or lewd. Iowa's Supreme Court reinforced legal marriage as the appropriate site for women's political representation in the years following the Civil War. The court affirmed seduction convictions when the woman could be constructed as easily influenced and thus not fully capable of free consent. The judicial system promoted essentialist stereotypes about women through its prosecution and conviction of "seducers." By 1876, seduction cases had firmly established the incapacity of any "chaste" woman to enter an extralegal sexual relationship. ${ }^{17}$

\section{Suffrage Debates in Reconstruction-Era Iowa}

Iowa's Supreme Court opinions defined the boundaries of criminal seduction within a political context of disagreement about the inclusion of African Americans and women in Iowa's franchise. Iowa was a state dominated by the Republican Party, a state labeled the "radical star" for its early enfranchisement of African American male voters, but in the years after the Civil War it also proposed, debated, and, ultimately failed to give adult women, black and white, the vote. In 1870 the Iowa legislature initially approved changes to Iowa's constitution that would have allowed women to vote, but approval was required a second time before the changes could be submitted to a popular vote for ratification. In 1872 the Iowa state senate failed to pass the suggested alterations. The state would have to wait for a future generation of suffragists, including Iowan Carrie Chapman Catt, to mobilize the political support necessary for women's enfranchisement. ${ }^{18}$

16. State v. Andre, 5 Iowa 389 (1857), 390.

17. Four criminal convictions of seduction were appealed to Iowa's Supreme Court before 1865 . The court reversed all of those decisions, primarily because the court was in the process of defining the limits and definitions of the criminal seduction statute.

18. Louise R. Noun, Strong-Minded Women: The Emergence of the Woman-Suffrage Movement in Iowa (Ames, 1969), 128-33; Robert Cook, Baptism of Fire: The Re- 
Ultimately, seduction cases such as State $v$. Bell affirmed a gendered concept of citizenship. While the 1870 and 1872 legislatures debated removing the word male from voting qualifications in Iowa's state constitution, criminal seduction convictions reinforced the conceptions of essential gender differences in the ability to reason and think. The court's sexual ideology helped justify the political exclusion of women from enfranchisement. The criminal system solidified gender stereotypes and, consequently, the sexes received unequal treatment under the law. Iowa presents us with a case study of how the legislature and the judicial system defined different legal and political obligations for the sexes during Reconstruction.

Reconstruction-era suffrage activists not only fought to enfranchise women, but they also employed universal rights arguments to combat the assertion that women should not vote because of their intellectual capacity. They employed equal rights ideologies against men like $\mathrm{H}$. R. Claussen, a senator who opposed woman suffrage. In 1872 Claussen gave a speech to the senate claiming that women's enfranchisement was "against public welfare." He based his claim on his belief that the female mind "is not original, not productive of great original ideas, but merely receptive." He warned that Iowa should not give "a voice to women, whose name is frailty." 19

In 1872 women lobbied state legislators to vote for the proposed enfranchisement amendment. In a letter to a newspaper, "Ruth" claimed that a Republican member of the state legislature had told her that he believed that there was "too much ignorant voting already, and that he was in favor of limiting male suffrage on the basis of intelligence." Ruth vigorously refuted his logic. Republicans themselves had labeled the right to vote an inalienable right; "It is too late now to throw this dust in our

publican Party in Iowa, 1838-1878 (Ames, 1994), 183; Robert R. Dykstra, Bright Radical Star: Black Freedom and White Supremacy on the Hawkeye Frontier (Cambridge, MA, 1993), 224-27. For a discussion of the different philosophies of Democrats and Republicans regarding state power and regulation of domestic life, see Rebecca Edwards, Angels in the Machinery: Gender in American Party Politics from the Civil War to the Progressive Era (New York, 1997), 12-35.

19. H. R. Claussen, "Woman Suffrage," Daily Iowa State Register, 3/30/1872; Daily Iowa State Register, 3/30/1873. For historical background on Claussen, see Wood, The Freedom of the Streets, 3. 
eyes and say 'all women shall not vote because a portion of them may be as ignorant as some men.' " 20

In 1871 and 1872, Iowa antisuffragists wrote letters to newspapers accusing Elizabeth Cady Stanton and Susan B. Anthony of destroying the marriage bond and correlating women's political enfranchisement with the destruction of marriage. In a letter in the Daily Iowa State Register, headed "Suffrage, and How the Women of Iowa Will Vote in 1872," "R. W. T" accused suffragists of working to destroy marriage and criticized Elizabeth Cady Stanton's speech "Marriage and Maternity" as obscene, containing words only used by prostitutes. The writer went on to accuse woman suffrage advocates of corrupting the "young and innocent, the wise and virtuous." 21

Woman suffrage, to "R. W. T.," was potentially more destructive to the republic than the secession of Southern states prior to the Civil War. "R. W. T." urged Iowans to send antisuffrage petitions to the state legislature to defeat woman suffrage and preserve "inviolate the Republic" that men had so recently died to preserve. Women's enfranchisement would cause "our dear little daughters" to become the prey of the "licentious libertine," because divorce would become easy to obtain. In fact, "R. W. T." believed that women's "inalienable rights" were violated by divorce, not by their inability to vote or serve in political office. ${ }^{22}$

Iowa Attorney General Henry O'Connor distanced himself from the suffrage movement as he argued before the Iowa Supreme Court that it should uphold seduction convictions. In 1871, amid increased concern that women's enfranchisement would cause sexual immorality, $\mathrm{O}^{\prime}$ Connor resigned as president of the Iowa Woman Suffrage Association. ${ }^{23}$ In June of the same year O'Connor argued against the appeal of Andrew Shean, whom he accused of being a "heartless coward" who took ad-

20. "Ruth," "A Few Thoughts on the Suffrage Question, by a Woman Who Wants to Vote," Daily Iowa State Register, 3/27/1872.

21. "R. W. T.," "Suffrage, and How the Women of Iowa Will Vote in 1872," Daily Iowa State Register, 8/10/1871. See also “R. W. T.," “For Woman Suffrage -No," Daily Iowa State Register, 10/26/1871.

22. "R. W. T.," "Suffrage."

23. Noun, Strong-Minded Women, 140-41, 182-85. 
vantage of Catherine Cavenaugh, a "poor girl" who gave Shean "her heart and her 'honorable' love." 24

\section{The Legal Narrative of Seduction in Reconstruction-Era Iowa}

In 1865, the final year of the Civil War, the Iowa Supreme Court affirmed the conviction in its first criminal seduction case, State v. Carron. ${ }^{25}$ The circumstances of the case were unusual for Reconstruction-era seduction cases, due to the young age of the victim. In Carron, the defendant sexually assaulted an 8-yearold girl and then reinitiated the relationship when she was 13 years old. The crime began when the defendant, a schoolteacher, boarded with the child's family from July 1857 until 1862. During that time he proceeded to engage in "unlawful commerce" with the child. ${ }^{26}$ After serving in the Union navy during the Civil War, he returned and reinitiated his sexual relationship with the girl, who by then was 13 years old, promised her marriage, and impregnated her.

The defense claimed that the girl was unchaste, as she had already been "debauched" by the defendant before he left for the navy. Ruling against him, the court, defining chastity as "actual personal virtue," declared that the girl "was chaste as to all the world except the defendant." The court found the victim to have been seduced because she was under the "influence and control he had unduly acquired over her." 27

Quite literally, the court accepted that the victim of seduction became corrupted as a result of the crime. The seducer drew his victim "aside from the paths of virtue, which she was honestly pursuing at the time the defendant approached her." 28 In the previous decade, the Iowa Supreme Court had defined chastity as a matter of physical virginity and the possession of a chaste "mind and sentiments." 29 To be led from the path of chastity

24. State v. Shean, 32 Iowa 88, "Brief for Appellee," 4.

25. State v. Carron, 18 Iowa 372 (1865).

26. Ibid., 373 .

27. Ibid., 375, 374 .

28. Ibid., 376 .

29. In State v. Andre, 395, 399, the court determined it erroneous to instruct the jury that "unchaste character means actual sexual intercourse" and that the statute was for the protection of the "pure in mind, for the innocent in heart." 
meant that the seducer corrupted the virtuous character of his victim.

The court defended its affirmation by noting that the girl was so young that she was "incapable of consenting to a marriage, and incapable of that unchaste mind and heart which would defeat the action." 30 Typical of seduction cases, the Supreme Court's opinion noted the influence that the man exerted in achieving his seduction; the seducer placed her "under his control." 31 The former schoolteacher was sentenced to five years imprisonment at the state penitentiary.

Over the years of Reconstruction, the major change in Iowa seduction convictions affirmed by the state Supreme Court was the age of the victims. In State v. Shean (1871), the next case affirmed after Carron (1865), the victim was 21 years old. In most of the seduction convictions affirmed by the court during the 1870s, the women had reached the age of majority. Iowa law considered these women as fully capable of marrying without their parents' permission. ${ }^{32}$ The Supreme Court determined that the legal logic of seduction - that a woman's reason could be manipulated through the strength of a seducer's mind-could apply just as easily to an adult woman as it did to the control and influence that a schoolteacher held over a child of 8 or 13.

The curious case of State $v$. Shean reveals how, in 1871, the court held that strength of reason was weaker for women than for men. The crime commenced when Andrew Shean proposed marriage to Catherine Cavenaugh. Shean, a farmer, lived about a mile from Cavenaugh's home, and the couple had "kept company" with each other for two years before the alleged seduction occurred. Cavenaugh would later testify that, on December 1, 1868 , she "permitted him to have intercourse with me, because I

30. State v. Carron, 377.

31. Ibid., 375, 374.

32. The prosecuting witness was above 18 years old in State $v$. Shean, 32 Iowa 88 (1871); State v. Savoye, 48 Iowa 562 (1878); State v. Wells, 48 Iowa 671 (1878); State v. Bell; State v. Curran, 51 Iowa 112 (1879); and State v. Deitrick, 51 Iowa 467 (1879). Aside from State v. Carron, two other cases were affirmed between the years 1865 and 1879 in which the prosecuting witness's age was lower than 18; in State v. Higdon, 32 Iowa 262 (1871), her age was 13; in State v. Bowmann, 43 Iowa 481 (1877), the prosecuting witness was 17 years old. 
expected him to marry me." After her child was born, Shean gave the child his last name, visited the child, and told Cavenaugh he would marry her. A jury in Clinton County convicted Andrew Shean of seduction, and he appealed to the Iowa Supreme Court. ${ }^{33}$

In Shean, the court defined all chaste women as a class of citizens who could be seduced from "a path of virtue." While the Supreme Court understood the victim of Carron to be legally too young to consent to marriage, even with her parents' permission, Catherine Cavenaugh, the victim in State v. Shean, was a 21-year-old woman. Carron used the statute of seduction to protect a 13-year-old girl and punish the man who violated her when she was 8 years old. Shean extended the same rationale to the protection of a 21-year-old woman and defined the offenses as identical.

Criminal enforcement of seduction justified the political exclusion of women as a class from enfranchisement. A seducer demonstrates that an independent woman's virtue is easily corrupted because she is not protected by the influence of a husband, and her weak powers of reason and intellect prevent her escape. ${ }^{34}$ Iowa's seduction statute, especially when applied to adult women, reinforced the assumption that women needed to be protected, not only from libertines but also from their own insufficient brainpower.

Andrew Shean violated the responsibilities of independent men who gain their legitimacy by protecting their household dependents. Shean was able to corrupt Cavenaugh, a previously "virtuous girl," because he promised a relationship he did not fulfill. ${ }^{35} \mathrm{He}$ damaged her ability to contract a legal marital relationship that would enable her to gain political representation of her interests to the state. The criminal statute of seduction enforced a conservative message bolstering the rights of husbands to represent their wives and political leaders to represent their male constituents. A seducer symbolized the tyranny that could

33. State v. Shean, 32 Iowa 88 (1871); State v. Shean, "Abstract of the Pleadings and Evidence," 3.

34. Elizabeth Barnes, States of Sympathy: Seduction and Democracy in the American Novel (New York, 1997), 8.

35. Ibid., 90. 
result from the breakdown of patriarchal institutions such as marriage.

In 1871, the year before Iowa's legislature would vote down the proposed suffrage amendment, a judge in Clinton County instructed the jury in 21-year-old Catherine Cavenaugh's seduction trial that "our statute is for the protection of the poor in mind, for the innocent in heart, who may have been led astray." 36 This discourse on women's capacity for intelligence occurred simultaneously in Iowa's newspapers and the state legislature in the early 1870s. Annie Savery, a women's rights activist, directly attacked the assertion that women were unsuitable voters because they were mentally inferior to men. In her speech to the Iowa Woman Suffrage Association at its 1871 convention in Des Moines, Savery declared, "Either you must grant that women are capable of self-government, or that morally and mentally they are inferior to all men and need guardians and legal restriction to keep them within the pale of civilization." 37 As Iowans debated what political and legal rights were owed to women, the Iowa Supreme Court began to affirm seduction convictions for adult women. Catherine Cavenaugh was 21 during the trial of Andrew Shean - the same age that male Iowans reached their majority and, of course, could cast a ballot.

\section{Overturning Seduction}

When the Iowa Supreme Court overturned seduction convictions in the 1870s, the justices provided instructive examples of how they interpreted an independent or "strong-minded" woman. Legal rhetoric correlated the strong-minded woman with licentiousness and vice - not an appealing candidate for enfranchisement. In 1876 a particularly revealing case, State v. Haven, reached the Iowa Supreme Court, which reversed the lower court's decision because the victim told the man that she did not intend to marry and thus, according to the court's reasoning, it would be impossible for her to be seduced. Chief Justice William Seevers, in his decision, found that the defendant had not used

36. State v. Shean, "Abstract of the Pleadings and Evidence," 22.

37. Annie Savery, "Woman Suffrage," Daily Iowa State Register, 10/21/1871. 
any arts, false promises, or seductive influences that caused her to succumb to a sexual relationship. ${ }^{38}$

Norman Haven was a bachelor who lived with his parents while 22-year-old Sarah Johnson boarded with his family to attend school. Johnson, the prosecutrix in this case, had remarked to several people that she never intended to marry, having previously rejected a proposal from a widower. While riding home from a church meeting, Haven wanted Johnson to promise to marry him if she ever decided to marry any man. A couple of times she turned him away when he tried to visit her room at midnight. She testified that, approximately two years after she had started boarding with the Havens, Norman came to her room and climbed in bed with her. "He said for me to keep still, or I would be hurt." She told him he would ruin her, but he replied that she should "know him well enough" to trust him. The next morning Haven told Johnson that he would not forsake her. She bore a child in April 1872. ${ }^{39}$

Although Johnson testified that Haven "had such an influence over me that I could not help believe what he told me," Chief Justice Seevers did not consider Haven's words to be evidence of seduction. He pointed to her testimony in the crossexamination that "he did not promise to marry me. . . . I told him at first I didn't intend to marry anybody; afterwards I told him I never should marry any one but him since this happened, but not before." 40

Johnson was 22 years old when the seduction occurred. Haven's lawyers pointed out Johnson's age during her crossexamination and queried her about living away from her mother for two years to attend school. The fact that Johnson was interested in education, along with her assertions to several people that she never wanted to marry, probably persuaded Justice Seevers that she was not a "seducible" woman. In fact, Haven's lawyer argued that Johnson "was and is very far from being a person of weak mind, that on the contrary she has more than ordinary strength of mind." 41

38. State v. Haven, 182.

39. State v. Haven, "Appellant's Abstract of Record," 2, 4.

40. State v. Haven, 182.

41. State v. Haven, "Appellants Argument," 2. 
Haven's defense lawyer correlated strength of mind with lewd and lascivious behavior. He accused Johnson of trying to "catch a bachelor" and claimed that Haven should not be punished for being seduced by a "designing and strong minded woman." The lawyer even quoted poetry to refute Haven's culpability for the illicit sexual relationship:

If the bold brigand my bright eyes should see,

I am the victor, - the captive is he! 42

Because the legal logic of seduction associated "strongminded" women with lewd and lascivious behavior, such independent women threatened the gendered ideology of the marital social contract. State $v$. Haven demonstrated that an educated, independent-minded woman fell outside of the court's protection. The prosecutorial powers of the state did not provide a legal remedy for women who did not fit the definition of a "seducible" woman.

The high court worked to separate the crime of seduction from rape by overturning misapplied seduction convictions. State v. Kingsley (1874) illustrates how the higher court viewed these problems. Eliza H. Brown, a 22-year-old resident of Delaware County, had found work at Allen Kingsley's cheese factory. After she had worked at the factory for two weeks, Kingsley approached her, claimed to love her, and attempted to kiss her. He also told her that no harm would come to her as a result of sexual intercourse, and if she got into "trouble he would see [her] out of it." That was the first time Kingsley had approached Brown physically or claimed that he felt affection for her. She pushed him away and told him that she did not "want any such actions." 43 In response, Kingsley threatened that if she did not submit he would fire her and hire someone to replace her. Brown testified that, after about half an hour, Kingsley "threw me down on the floor and accomplished his desire." After raping her, he threatened to fire her unless she continued to have sexual relations with him. Brown stated that, although she did

42. Ibid., 4, 5,

43. State v. Kingsley (1874), 39 Iowa 439; State v. Kingsley, "Abstract of Record," 3. 
not give her consent to future intercourse, she did not resist "through fear of being thrown out of work." 44

Brown bore a child in March 1871, and in April Delaware County indicted Allen Kingsley for the crime of seduction. The district court determined that Kingsley's threats to discharge Brown from the cheese factory induced her to "yield to his wishes" and "use less resistance than she otherwise would have done." 45 However, the Iowa Supreme Court overturned the verdict because Brown said the first act of "debauchery" was against her will and her consent. She did not believe that Kingsley loved her or that he would take care of her if she became pregnant. ${ }^{46}$

State v. Kingsley reveals how the Iowa Supreme Court constructed seduction as a crime committed against weak-minded women. But Eliza Brown knew her own mind. She was not a seducible victim, nor was she susceptible to Allen Kingsley's deceiving promises. The justices did not believe that Kingsley's threats "influenced" his victim's will. The court did not see the incident as seduction because Kingsley's statements did not convince Brown-initially, she was simply overcome by physical force. Justice James Day, who wrote the opinion for the court, stated that this could not be seduction because Brown "persists in declaring that defendant accomplished his purpose by force and against her will." 47 Furthermore, they viewed her subsequent response to his threats as voluntary consent to sexual intercourse.

In Brown's cross-examination, her testimony is clear: she saw through Allen Kingsley's lies, and she did not succumb to him out of any weakness in her mind. When Kingsley's lawyer cross-examined her, Brown remained firm about her opinions of Kingsley and his actions towards her.

Kingsley's lawyer: "Did you believe he loved you?"

Brown: "No Sir."

Kingsley's lawyer: "Did you believe there was no risk to run?"

Brown: "No Sir."

44. Ibid., 3, 7.

45. State v. Kingsley, 9, and "Abstract of Record," 13.

46. State v. Kingsley, 440-41.

47. Ibid., 441. 
Kingsley's lawyer: "Did you believe his assurance that there was no hurt in it?"

Brown: "No sir. I believed there would be hurt in it; did not believe his assurance to the contrary."

Kingsley's lawyer: "You stated in your direct examination that he threw you on the floor?"

Brown: "Yes sir, he did."

Kingsley's lawyer: "Could you not have prevented that had you tried right hard?"

Brown: "No sir."

Kingsley's lawyer: "Did you consent to the intercourse?"

Brown: "No sir. The intercourse was against my consent and against my will." 48

Justice Day stated that if the above testimony was true, then Kingsley had raped Brown, but he also believed that the evidence demonstrated that she had submitted to Kingsley "voluntarily and without the employment of artifice, promises, or persuasion." The court implicitly defined the woman who cannot be seduced, who does not believe the reasoning of her seducer, as a woman who is unchaste, lewd, and, therefore, deviant. For a crime to be committed, the woman must be raped or seduced; threats to terminate employment combined with a first instance of nonconsensual sex did not fit the justices' conception of the crime of seduction. As Justice Day wrote in his opinion, "The defendant either committed the crime of seduction, or he did not." The Iowa Supreme Court overturned Kingsley's guilty convictions because of Brown's state of mind as seen in the above testimony. ${ }^{49}$

The true victim of seduction, in Justice Day's mind, must consent for seduction to occur, but such consent would not be voluntary because she had been deceived, fooled, or influenced by a stronger mind. The court did not construct Eliza Brown as a victim of seduction because her employer had used undue influence to get sex through the use of threats. Additionally, Brown understood his words to be threats, not false promises. Her mind was not deceived. A true seduction victim was not capable of understanding that her seducer was lying to her. The

48. State v. Kingsley, "Abstract of Record," 6.

49. Ibid., 441. 
seducer possessed superior oratory skills, and he convinced his victims through speech. Justice Day dismissed the fact that Brown was threatened with the loss of her job; he rejected the economic consequences of dismissal as a form of seductive "persuasion." According to Day, in spite of Brown's previous state of virginity, she was not "led from the path of virtue by seductive arts." 50

Iowa's legal code classified seduction, like rape, as an offence against an individual. The Supreme Court stated in 1870 that the victim of seduction, like a victim of rape, could be questioned about her previous sexual history. ${ }^{51}$ For both seduction and rape, the defendant could not be convicted on the testimony of the person injured without corroborating evidence; her testimony about the crime was not sufficient to sustain a guilty conviction. ${ }^{52}$ Although rape, like seduction, was classified as a crime against an individual, a rape victim did not lose her virtuous character in the eyes of the law. The rape victim understood the corrupt nature of her attacker, but a victim of seduction mistakenly trusted a sexual predator. It is not surprising that lower courts confused the crimes of rape and seduction, as they dealt with similar issues of consent and force. In State $v$. Tarr, the court ruled that a jury could convict a defendant on a rape charge even if the victim did not resist if the jury determined that "she was idiotic or of imbecile mind." 53

The Iowa Supreme Court, during Reconstruction, established that physical force could not play a role in a seduction conviction; the court's interpretation of seduction was unclear before lower court cases reached the state Supreme Court in the 1870s. Eliza Brown, according to the court, was neither seduced nor raped. Iowa's statutory age for rape remained at 10 years old for girls until 1886, when the legislature raised the age to 13 in response to a Woman's Christian Temperance Union national campaign

50. Ibid., 440, 441.

51. State v. Sutherland, 30 Iowa 570 (1870), 573.

52. State v. Andre, 399; State v. Tulley, 18 Iowa 88 (1864), 89.

53. Code of Iowa, 1873, ch. 2, § 3861; State v. Tarr, 28 Iowa 397. For a discussion of interpretations of rape statutes when the victims were developmentally disabled, see Diane Miller Sommerville, Rape and Race in the Nineteenth-Century South (Chapel Hill, NC, 2005), 311n33. 
to raise the age of consent. ${ }^{54}$ Iowa's Code of 1878 defined males as attaining their majority at the age of 21 , and women at 18 years unless they married earlier with parental consent. Just as a man could be convicted of raping a woman over the age of 18 , he could be convicted of seduction even if that woman had reached her majority. ${ }^{55}$ For girls or women above the age of consent, rape was defined as carnal knowledge "by force and against her will." 56

Iowa's courts could not provide a legal remedy for Eliza Brown because the prosecutorial powers of the state benefited a particular type of woman - the woman who consented under the influence of a male's intellectual strength. Eliza Brown's circumstances lay outside the scope of Iowa's seduction statute as defined by the Supreme Court justices. State v. Haven and State $v$. Kingsley demonstrate that educated, independent-minded women fell outside the court's protection. The court reserved the seduction statute for victims like Nancy Haygood of the 1878 Bell case.

\section{Conclusion}

Republican political theory suggested that women freely consented to political representation by their husbands when they entered a "true" marriage-a marriage with a man who would uphold his marriage vows and represent the interests of his household to the state. ${ }^{57}$ Iowa citizens who opposed woman suffrage argued that women did not require the vote because faithful husbands would represent the interests of their wives. Those citizens viewed suffrage as a threat to the sexual morality of Iowa residents. ${ }^{58}$ Iowa legislators used this family preservation

54. Code of Iowa, 1873, ch. 2, § 3861. On Frances Willard and the Woman's Christian Temperance Union's campaigns to raise the age of consent, see Jane E. Larson, "'Even a Worm Will Turn at Last:' Rape Reform in Late NineteenthCentury America," Yale Journal of Law and the Humanities 9 (1997), 1-71; and Linda R. Hirshman and Jane E. Larson, Hard Bargains: The Politics of Sex (New York, 1998), 126-37. For discussion of the age-of-consent law in late nineteenthcentury Iowa and its prosecution, see Sharon E. Wood, The Freedom of the Streets, 4, 134-36, 149-50.

55. Code of Iowa, 1873, ch. 1, § 2186, 2521; ch. 4, § 2237.

56. Code of Iowa, 1873, ch. 2, § 3861; Briggs, History of Social Legislation, 52.

57. Pateman, The Sexual Contract.

58. “R. W. T.," “For Woman Suffrage-No!” 
rhetoric to justify their rejection of the proposed female suffrage amendments in 1872. During the debates over the amendments, Senator Benjamin Richards of Dubuque warned that the proposal must be defeated "for the sake of the family" and that the addition of woman suffrage would disgrace the state of Iowa. ${ }^{59}$

After Iowa's legislature voted down the proposed enfranchisement of women, an appalled Annie Savery wrote a letter to the Daily Iowa State Register, responding to Richards. She asked how liberty could possibly promote immorality in white women's character: "Why, sir, in the case of the black woman subject to her master, we said that slavery was the cause of her social sin. But in the case of the white woman, you declare that freedom is dangerous to her morality! Is this the secret of your opposition? Are the women of Iowa so corrupt, so inherently immoral that they cannot be trusted with the ballot?" 60

Savery pointed out the sexual inequality embedded within the logic of criminal seduction: the seducible women of Iowa could not be trusted with the ballot. If a deceiving would-be lover could seduce a woman, politicians making false promises might just as easily win her over.

Women's rights rhetoric shifted after the defeat of equal rights arguments. Equal rights rhetoric had failed to enfranchise women after the Civil War. ${ }^{61}$ After the close of Reconstruction, the Woman's Christian Temperance Union chose to employ a politics of respectability that promoted the image of women as wives and mothers. ${ }^{62}$

The prosecution of sex crimes, such as seduction, would play a critical role in the conservative retrenchment during the latter years of Reconstruction and the Gilded Age. As the Reconstruction era drew to a close, Iowa's Supreme Court affirmed that women and men would not be treated equally under the law.

59. Annie Savery, "Senator Richards and 'His Heavenly Homes,' " Daily Iowa State Register, 3/26/1872.

60. Ibid.

61. Ellen Carol DuBois, "Outgrowing the Compact of the Fathers: Equal Rights, Woman Suffrage, and the United States Constitution, 1820-1878," Journal of American History 74 (1987), 81-113.

62. For a discussion of how activists created a "language of virtue and vice into a code of class," see Hirshman and Larson, Hard Bargains, 124-41. 
The prosecution of seduction demonstrates how Iowa courts promoted concepts of sexual difference that justified women's political exclusion from the franchise. A gendered concept of citizenship rights and obligations justified the unequal treatment of women and their exclusion from full political participation in the state. 